\title{
Monitoring Tetranychus urticae Koch (Acari: Tetranychidae) resistance to abamectin in vineyards in the Lower Middle São Francisco Valley
}

\author{
Vaneska B. Monteiro a, *, Manoel G.C. Gondim Jr. a , José E. de M. Oliveira ${ }^{\text {b }}$ \\ Herbert A.A. Siqueira ${ }^{a}$, Josilene M. Sousa ${ }^{a}$ \\ a Departamento de Agronomia - Entomologia, Universidade Federal Rural de Pernambuco, Rua Dom Manoel de Medeiros s/n, Dois Irmãos, 52171-900 \\ Recife, PE, Brazil \\ ${ }^{\mathrm{b}}$ Embrapa Semiárido, Entomologia, Br 428 Km 152, Caixa Postal 23, 56302-970 Petrolina, PE, Brazil
}

\section{A R T I C L E I N F O}

\section{Article history:}

Received 21 August 2014

Received in revised form

12 December 2014

Accepted 21 December 2014

Available online

\section{Keywords}

Two-spotted spider mite

Resistance

Chemical control

Grape

\begin{abstract}
A B S T R A C T
In the Lower Middle São Francisco Valley, Tetranychus urticae Koch is controlled by the application of acaricides; however, the intensive use of these products in this region has caused control failures in the field. In the present study, concentration-response curves were constructed periodically to monitor the toxicity of abamectin to T. urticae in two vineyards over two years. Diagnostic concentrations of $1 \mathrm{mg}$ and $9 \mathrm{mg}$ of abamectin/L water were established based on the monitoring period to detect T. urticae resistance in different vineyards in the region. Concentration-response curves were obtained for abamectin, bifenthrin and carbosulfan for the populations considered resistant to abamectin. T. urticae were confined in arenas on cotyledonary leaf discs from jack bean (Canavalia ensiformis L.) that had been immersed in acaricide solution. Mite mortality was assessed after $48 \mathrm{~h}$ of exposure to the acaricides. The lethal concentration (LC) values varied over time in both of the vineyards studied, which was most likely a result of crop management. An additional 35 vineyards were sampled, and 20 additional populations were established. The results indicated that $45 \%$ of the populations exposed to the $9 \mathrm{mg} / \mathrm{L}$ abamectin diagnostic concentration experienced less than $80 \%$ mortality and were considered resistant to abamectin. The frequency of resistant mites ranged from $4.1 \%$ to $80.4 \%$. The resistance ratio ranged from 2406-fold to 8272-fold compared to susceptible populations in the laboratory. Resistance to bifenthrin was also confirmed in the present study, though resistance to carbosulfan was not. No cross-resistance between abamectin and bifenthrin was observed though this requires further investigation.
\end{abstract}

(C) 2014 Elsevier Ltd. All rights reserved.

\section{Introduction}

The two-spotted mite Tetranychus urticae Koch is an important grapevine pest in several parts of the world (Schruft, 1985; Duso et al., 2010; James and Prischmann, 2010), including the Lower Middle São Francisco Valley (Haji and Alencar, 2000; Oliveira and Moreira, 2009; Domingos et al., 2014). T. urticae causes chlorotic spots on leaves that can become reddened, necrotic and dry. High infestations can cause defoliation and browning (Carmona, 1996; Haji et al., 2001b; Botton, 2005; Oliveira and Moreira, 2009). Other mite species are also important pests in the region and include the

\footnotetext{
* Corresponding author.

E-mail addresses: vaneska_barbosa@hotmail.com (V.B. Monteiro), mguedes@ depa.ufrpe.br (M.G.C. Gondim Jr.), eudes.oliveira@embrapa.br (J.E. de M. Oliveira), siqueira@depa.ufrpe.br (H.A.A. Siqueira), podos@ig.com.br (J.M. Sousa).
}

broad mite Polyphagotarsonemus latus (Banks) and the mango spider mite Oligonychus mangiferus (Rahman and Sapra) (Haji and Alencar, 2000; Domingos et al., 2014).

Grapes produced in the Lower Middle São Francisco Valley are mainly destined for export. To meet the export market demands, the product must be certified by different entities whose standards meet the requirements of importing countries (Fachinello, 2001; Haji et al., 2001a; Silva et al., 2001). Certification provides assurance to consumers regarding product quality (Fachinello, 2001; Pinheiro and Adissi, 2007). However, only three acaricides that are registered in Brazil for the control of grapevine mites by the Ministry of Agriculture, Livestock and Food Supply (Ministério da Agricultura, Pecuária e Abastecimento - MAPA) are also accepted by importing countries: abamectin, bifenthrin and carbosulfan (AGROFIT, 2013). Farmers avoid using more than one acaricide because they must also use insecticides to control thrips and fungicides to control the downy mildew fungus Plasmopara viticola 
(Berkeley and M. A. Curtis) Berlese \& De Toni and grape powdery mildew fungus Erysiphe necator Schwein, which are important diseases affecting grapevines. Thus, farmers tend to use a broadspectrum acaricide such as abamectin that controls tetranychids (T. urticae and O. mangiferus) and tarsonemids (P. latus). Apparently, this practice has promoted the intensive use of abamectin in the region, which has elevated the selective pressure on these populations and increased the number of reports of control failures in the field as a result of the emergence of populations with a high frequency of resistant individuals.

T. urticae stands out among arthropods for being resistant to a large number of acaricides/insecticides (Whalon et al., 2008), and resistance mechanisms have been recently reviewed (van Leeuwen et al., 2010). Cross and multiple resistant species have also been reported for this mite in several parts of the world (Sato et al., 2005; Kim et al., 2006; Kwon et al., 2010; Nicastro et al., 2010). The short life cycle, reproductive mode and high biotic potential of $T$. urticae favor the rapid development of resistance to several acaricides (Stumpf and Nauen, 2001). In field populations, resistance can be easily and quickly assessed through toxicity tests using discriminating concentrations (Roush and Miller, 1986). These concentrations cause mortality in most of the susceptible individuals of a population, which differentiates these from resistant individuals (Kabir et al., 1991; Shah et al., 2002; Yu, 2008; Sato et al., 2009). The discriminating concentration is expressed by values that are usually between the lethal concentrations (LCs) $\mathrm{LC}_{95}$ and $\mathrm{LC}_{99}$ of susceptible populations (Halliday and Burnham, 1990). Monitoring of T. urticae resistance using discriminating concentrations was performed for abamectin and hexythiazox in the United States (Knight et al., 1990), for clofentezine and fenbutatin oxide in Australia (Herron et al., 1997), for propargite in New Zealand (Shah et al., 2002), and for bifenazate, acequinocyl, abamectin, milbemectin, bifenthrin, cyflumetofen, etoxazole and spiromesifen in the Netherlands (Khajehali et al., 2011). In Brazil, tests using discriminating concentrations were conducted in the state of São Paulo using abamectin, fenpyroximate and milbemectin in $T$. urticae populations from several crops (Sato et al., 2009; Nicastro et al., 2010).

The aim of the present study was to provide information on the frequency of $T$. urticae resistance to abamectin in grapevines in the Lower Middle São Francisco Valley; concentration-response curves were periodically performed to establish diagnostic concentrations and monitor the toxicity of abamectin to T. urticae in the region studied. Toxicity tests were also conducted for bifenthrin and carbosulfan, which are the other acaricides registered for $T$. urticae control in grapevines in Brazil, to assess if cross-resistance occurs in the region studied.

\section{Materials and methods}

\subsection{Tested acaricides}

The experiments were conducted using the acaricide abamectin (Kraft 36 EC, Cheminova Brasil Ltda., São Paulo, Brazil), bifenthrin (Talstar CE, FMC Química do Brasil Ltda., Batatais, Brazil) and carbosulfan (Marshal 400 SC, FMC Química do Brasil Ltda., Campinas, Brazil).

\subsection{Monitoring abamectin toxicity to T. urticae over time in two vineyards}

\subsubsection{Obtaining and maintaining T. urticae populations}

Grapevine leaves were collected from two properties in the municipality of Petrolina, state of Pernambuco that reported control failures using abamectin: population 1 ( $9^{\circ} 20^{\prime} 10.86^{\prime \prime} \mathrm{S}$; $\left.40^{\circ} 38^{\prime} 51.43^{\prime \prime} \mathrm{W}\right)$ and population 2 ( $\left.9^{\circ} 17^{\prime} 45.82^{\prime \prime} \mathrm{S} ; 40^{\circ} 32^{\prime} 51.47^{\prime \prime} \mathrm{W}\right)$. The samples were collected from July 2011 to September 2013 with two to three month intervals between collections. Leaf samples were transported to the Laboratory of Acarology of the Federal Rural University of Pernambuco (Universidade Federal Rural de Pernambuco - UFRPE) in paper bags that were placed in Styrofoam boxes. In the laboratory, the mites were transferred to jack bean plants (Canavalia ensiformis L.) that were maintained at $25^{\circ} \mathrm{C} \pm 1{ }^{\circ} \mathrm{C}$ temperature and $85 \pm 10 \%$ relative humidity for a $12 \mathrm{~h}$ photoperiod.

\subsubsection{Abamectin bioassay}

Toxicity tests were conducted according to Method $\mathrm{N}^{\circ} 4$ of the series of methods to test susceptibility from the Insecticide Resistance Action Committee (IRAC, 2009). A series of 10-fold dilutions of abamectin $\left(0.01 ; 0.1 ; 1 ; 10 ; 100\right.$; and $\left.1000 \mathrm{mg} \mathrm{L}^{-1}\right)$ was prepared to establish an "all or none" response. The acaricide application was conducted by immersing $C$. ensiformis cotyledonary leaf discs $(5 \mathrm{~cm}$ diameter) for $5 \mathrm{~s}$ in a beaker containing the different abamectin concentrations. The control treatment corresponded to the immersion of leaf discs in distilled water. After immersion, the discs were dried at room temperature for $30 \mathrm{~min}$. The experimental unit consisted of a $9 \mathrm{~cm}$ diameter Petri dish, into which $1 \mathrm{~cm}$ high polyethylene foam and filter paper (both $9 \mathrm{~cm}$ diameter) were placed. The leaf discs were placed on the filter paper, and the edges were covered with paper towel pieces to prevent the mites from escaping. The Petri dishes were moistened with distilled water to maintain leaf disc turgidity. Ten T. urticae adult females (F1 generation) were transferred to each experimental unit. Each concentration and the control treatment had three replicates, for a total of 30 mites per treatment. Mortality was assesses $48 \mathrm{~h}$ after treatment by counting the total number of live and dead mites per replicate. Mites that did not walk at least a distance corresponding to their body length after being touched with an $\mathrm{N}^{\circ} 000$ brush were considered dead. The mortality percentage of the concentrations was corrected for the mortality of the control (Abbott, 1925).

Based on the "all or none" response assays, seven to eight concentrations diluted by a factor of two were established for the definitive bioassays. These bioassays were performed as aforementioned, but the entire procedure was repeated twice on different days for a total of 60 mites per concentration. The mortality data were subjected to Probit analysis (Finney, 1971) after correction for control mortality (Abbott, 1925). The software POLOPlus 2.0 (LeOra-Software, 2005; Petaluma, USA) was used to obtain the concentration-response curves. The resistance ratios $\left(R R_{50}\right)$ of the resistance populations were calculated for a 95\% confidence interval (CI) using the method described by Robertson and Preisler (1992).

\subsection{Monitoring abamectin resistance in T. urticae populations over the Valley area}

\subsubsection{Obtaining and maintaining T. urticae populations}

Grapevine leaves were collected from 35 commercial plantations in the Lower Middle São Francisco Valley from January 2013 to April 2013 for obtaining and establishing T. urticae populations under laboratory conditions. The sampling sites were georeferenced with the aid of a global positioning system (GPS) (Fig. 1). The leaf samples were transported to the Embrapa SemiArid (Embrapa Semiárido) facility in paper bags that were placed in Styrofoam boxes. In the laboratory, the mites were transferred to C. ensiformis plants that were kept at $25^{\circ} \mathrm{C} \pm 1{ }^{\circ} \mathrm{C}$ temperature and $85 \pm 10 \%$ relative humidity for a $12 \mathrm{~h}$ photoperiod. As a susceptible standard, a T. urticae population collected from Gossypium hirsutum L. plants in the municipality of Piracicaba, São Paulo State, was used $\left(22^{\circ} 42^{\prime} 48.22^{\prime \prime}\right.$ S; $\left.47^{\circ} 37^{\prime} 34.03^{\prime \prime} \mathrm{W}\right)$. This population was collected in 


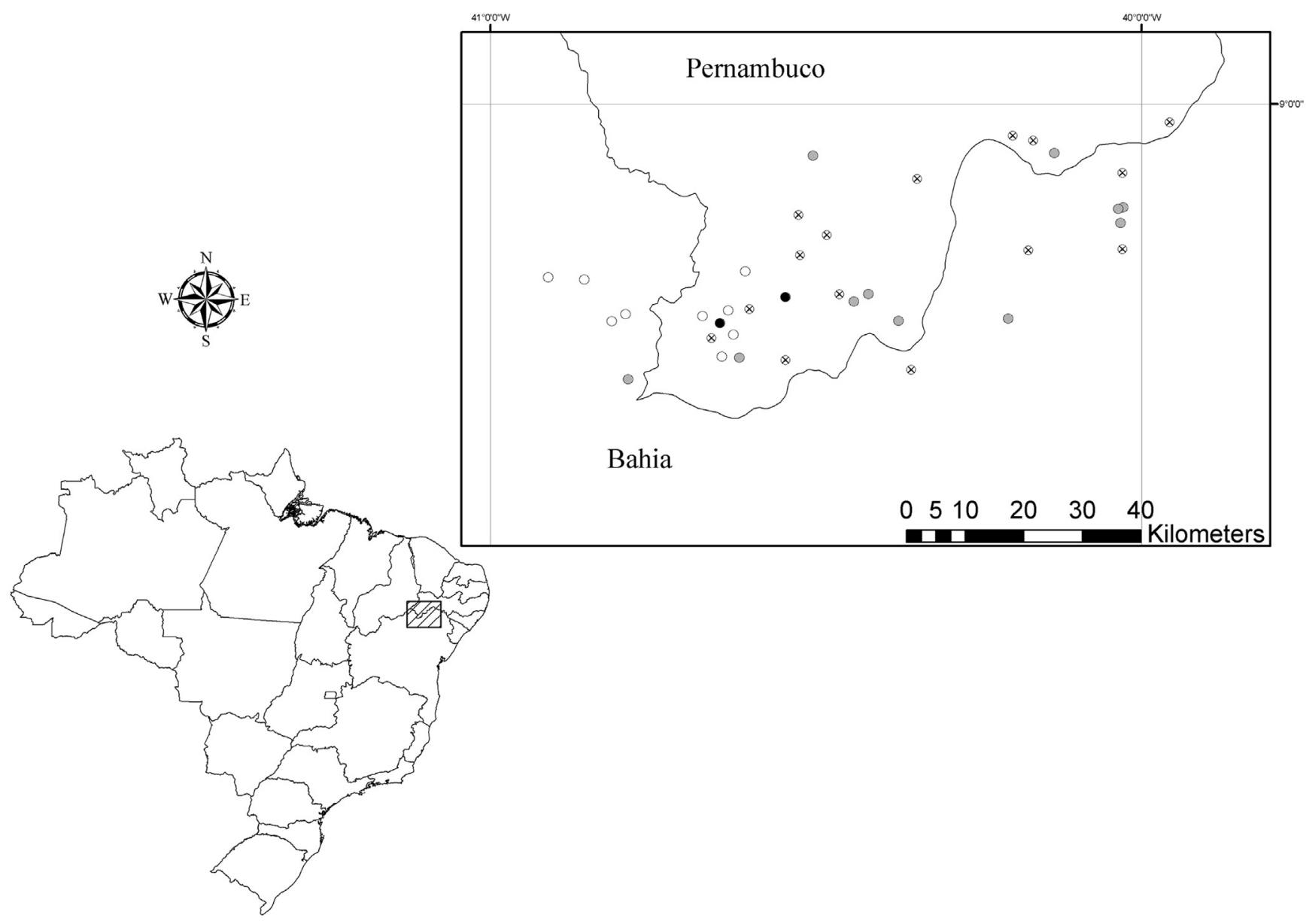

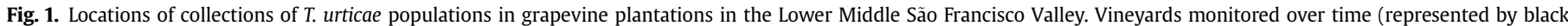

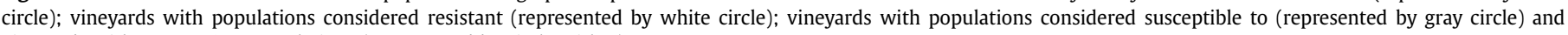
vineyards with no $T$. urticae populations (represented by circle with $\mathrm{x}$ ).

2000 and maintained in the Laboratory of Acarology of the UFRPE with no insecticide pressure since then.

\subsubsection{Bioassay}

For this monitoring, diagnostic concentrations of abamectin of $1 \mathrm{mg} / \mathrm{L}$ and $9 \mathrm{mg} / \mathrm{L}$ were respectively used based on the $\mathrm{LC}_{50}$ and $\mathrm{LC}_{95}$ midpoint estimates from overtime monitoring experiment (item 2.2.). The $\mathrm{LC}_{95}$ estimate average virtually matched the field recommended dose of abamectin (AGROFIT, 2013). The procedures were similar to the experiment previously described regarding acaricide application, arena manufacturing (experimental units) and mite confinement and assessment. Each bioassay corresponded to one population with three treatments; two corresponded to the diagnostic concentrations ( $1 \mathrm{mg} / \mathrm{L}$ and $9 \mathrm{mg} / \mathrm{L}$ ) and another corresponded with distilled water only (control). Each treatment consisted of five experimental units totaling 50 mites per treatment. Each bioassay was repeated three times on different days for a total of 150 mites per treatment. After mite confinement, the experimental units were placed at $25 \pm 1{ }^{\circ} \mathrm{C}$ temperature and $85 \pm 10 \%$ relative humidity for a $12 \mathrm{~h}$ photoperiod. The percentage mortality of the concentrations was corrected for the control mortality (Abbott, 1925). The population that had less than $80 \%$ mortality when exposed to the $9 \mathrm{mg} / \mathrm{L}$ abamectin diagnostic concentration was considered resistant to this acaricide.

\subsection{Bioassays of bifenthrin and carbosulfan toxicity to T. urticae populations resistant to abamectin}

For the populations considered resistant to abamectin (mortality $<80 \%$ in the $9 \mathrm{mg} / \mathrm{L}$ diagnostic concentration), toxicity tests were performed according to Method $\mathrm{N}^{\mathrm{O}} 4$ of the series of methods for susceptibility tests from the Insecticide Resistance Action Committee (IRAC, 2009). Bifenthrin and carbosulfan concentrations were diluted by a factor of $10(0.1 ; 1 ; 10 ; 100 ; 1000$ and $10,000 \mathrm{mg})$ per liter of solution. Acaricide application, arena manufacturing, mite confinement and assessment and data analysis were performed in a similar manner as the preliminary test for abamectin toxicity monitoring. From the preliminary tests, seven to eight concentrations diluted by a factor of two were established among concentrations that caused approximately 0 and 100\% mite mortality. All of the acaricide application, arena manufacturing, mite confinement and assessment and data analysis procedures were similar to the bioassay for abamectin toxicity monitoring. A correlation was performed between the $\mathrm{LC}_{50} \mathrm{~S}$ and $\mathrm{LC}_{95} \mathrm{~S}$ of bifenthrin and abamectin for each population resistant to both acaricides using the PROC CORR procedure in the program SAS (SAS Institute, 2002; Cary, USA). 


\section{Results}

\subsection{Monitoring abamectin toxicity to T. urticae over time in two} vineyards

The $\mathrm{LC}_{50}, \mathrm{LC}_{80}$ and the $\mathrm{LC}_{95}$ of population 1 ranged from 0.46 to $2.98,0.93$ to 6.85 and $1.79-15.55 \mathrm{mg} / \mathrm{L}$, respectively. The $\mathrm{LC}_{50}, \mathrm{LC}_{80}$ and the $\mathrm{LC}_{95}$ of population 2 ranged from 0.62 to $4.53,1.38$ to 10.15 and $2.90-21.91 \mathrm{mg} / \mathrm{L}$ (Table 1 ), respectively.

\subsection{Monitoring abamectin resistance in T. urticae populations over the Valley area}

Thirty-five farms in the Lower Middle São Francisco Valley were visited, but T. urticae was not found in 15 farms (Fig. 1). The $1 \mathrm{mg} / \mathrm{L}$ diagnostic concentration caused less than $50 \%$ mortality to populations $3,4,5,6,7,8,9,10,11,15$ and 17 and higher than $50 \%$ mortality to the remaining populations (populations $12,13,14,16$, $18,19,20,21$ and 22). The $9 \mathrm{mg} / \mathrm{L}$ diagnostic concentration caused less than $80 \%$ mortality to populations $3,4,5,6,7,8,9,10$ and 11, which were considered resistant to abamectin; and more than $80 \%$ mortality to the remaining populations $(12,13,14,15,16,17,18,19$, 20, 21 and 22), which were considered susceptible to abamectin (Fig. 2). The frequency of resistant mites when subjected to the $9 \mathrm{mg} / \mathrm{L}$ diagnostic concentration ranged from $4.14 \%$ to $80.40 \%$.

The populations considered resistant to abamectin when assessed by concentration-response curves showed resistance ratios ranging from 2406-fold (Population 10) to 8272-fold (Population 8 ) compared to a susceptible population in the laboratory (Table 2).

\subsection{Bioassays of bifenthrin and carbosulfan toxicity to T. urticae populations resistant to abamectin}

The carbosulfan toxicity tests estimated an $\mathrm{LC}_{50}$ of 715 and $2132 \mathrm{mg} / \mathrm{L}$ and $\mathrm{LC}_{95}$ of 2462 and $11,095 \mathrm{mg} / \mathrm{L}$ for populations 5 and

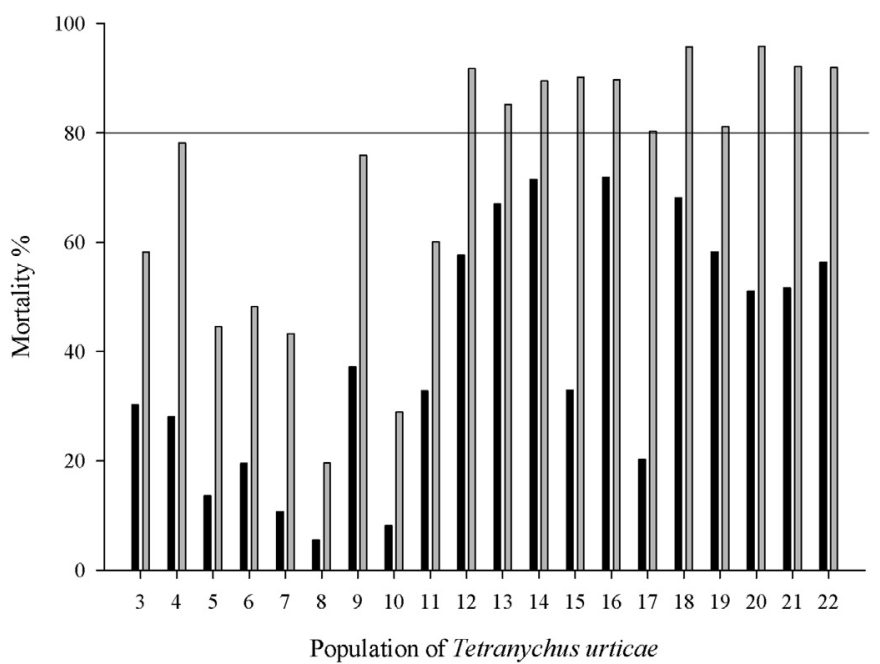

Fig. 2. Percentage mortality of T. urticae populations collected in vineyards of the Lower Middle São Francisco Valley subjected to diagnostic concentrations of abamectin $-1.0 \mathrm{mg} / \mathrm{L}$ (black bar) and $9.0 \mathrm{mg} / \mathrm{L}$ (gray bar).

6 , respectively. The resistance ratios ranged from 1 - to 3 -fold compared to the susceptible population. The bifenthrin toxicity tests estimated an $\mathrm{LC}_{50}$ of 1411 to $4271 \mathrm{mg} / \mathrm{L}$ for populations 8 and 3, respectively, whereas the $\mathrm{LC}_{95}$ varied from 8378 to $24,792 \mathrm{mg} / \mathrm{L}$ for populations 6 and 3, respectively. The resistance ratios ranged from 162- to 489-fold compared to the susceptible population (Table 3). The correlation between the $\mathrm{LC}_{50} \mathrm{~S}\left(\mathrm{R}^{2}=0.24 ; \mathrm{P}=0.50\right)$ and $\mathrm{LC}_{95 \mathrm{~s}}\left(\mathrm{R}^{2}=0.16 ; \mathrm{P}=0.65\right)$ of abamectin and bifenthrin were not significant (SAS Institute, 2002).

Table 1

Abamectin toxicity over time for two T. urticae populations collected in grapevines of the Lower Middle São Francisco Valley from July 2011 to September 2013.

\begin{tabular}{|c|c|c|c|c|c|c|c|c|}
\hline Population & Collection date & $N^{\mathrm{a}}$ & $\chi^{2}(\mathrm{DF})$ & Slope $\pm S E^{b}$ & $\mathrm{LC}_{50}(95 \% \mathrm{CI})^{\mathrm{C}}$ & $\mathrm{LC}_{80}(95 \% \mathrm{CI})^{\mathrm{C}}$ & $\mathrm{LC}_{95}(95 \% \mathrm{CI})^{\mathrm{C}}$ & $\mathrm{RR}_{50}(95 \% \mathrm{CI})^{\mathrm{d}}$ \\
\hline \multirow[t]{12}{*}{1} & $\mathrm{Jul} / 11$ & 355 & $0.67(4)$ & $1.83 \pm 0.30$ & $0.63(0.33-0.90)$ & $1.83(1.44-2.36)$ & $5.00(3.63-8.51)$ & $1.4(0.6-3.1)$ \\
\hline & Aug/11 & 345 & $1.79(4)$ & $1.98 \pm 0.28$ & $0.97(0.63-1.28)$ & $2.59(2.14-3.31)$ & $6.58(4.85-10.65)$ & $2.1(1.0-4.5)$ \\
\hline & Oct/11 & 299 & $0.62(4)$ & $2.81 \pm 0.24$ & $0.46(0.15-0.72)$ & $0.93(0.58-1.22)$ & $1.79(1.36-3.64)$ & - \\
\hline & Feb/12 & 354 & $2.67(4)$ & $2.50 \pm 0.24$ & $1.09(0.92-1.30)$ & $2.73(2.19-4.04)$ & $4.95(3.85-7.12)$ & $2.4(1.2-4.9)$ \\
\hline & Apr/12 & 347 & $2.49(4)$ & $2.94 \pm 0.29$ & $1.09(0.93-1.97)$ & $2.12(1.84-2.61)$ & $3.98(3.14-5.53)$ & $2.3(1.2-4.8)$ \\
\hline & Jun/12 & 330 & $2.05(4)$ & $2.01 \pm 0.21$ & $1.29(1.02-1.59)$ & $3.39(2.83-4.42)$ & $8.49(6.19-13.33)$ & $2.8(1.3-5.7)$ \\
\hline & Sep/12 & 367 & $5.35(4)$ & $2.13 \pm 0.19$ & $1.05(0.77-1.39)$ & $2.62(2.20-3.60)$ & $6.22(4.00-13.18)$ & $2.3(1.1-4.6)$ \\
\hline & Nov/12 & 349 & $4.48(4)$ & $2.83 \pm 0.17$ & $1.81(1.32-2.42)$ & $5.16(3.98-8.38)$ & $14.01(8.58-31.72)$ & $3.9(1.9-7.9)$ \\
\hline & Feb/13 & 340 & $3.61(4)$ & $1.68 \pm 0.19$ & $0.85(0.63-1.00)$ & $2.69(2.20-3.60)$ & $8.04(5.59-13.83)$ & $1.8(0.9-3.8)$ \\
\hline & May/13 & 343 & $5.16(4)$ & $2.44 \pm 0.21$ & $2.66(2.04-3.48)$ & $5.87(4.66-9.03)$ & $12.50(8.29-24.62)$ & $5.7(2.8-11.5)$ \\
\hline & $\mathrm{Jul} / 13$ & 345 & $2.22(4)$ & $2.25 \pm 0.20$ & $2.90(2.44-3.44)$ & $6.85(5.80-8.78)$ & $15.55(11.67-23.06)$ & $6.2(3.0-12.6)$ \\
\hline & Sep/13 & 357 & $1.80(4)$ & $2.37 \pm 0.21$ & $2.98(2.53-3.50)$ & $6.74(5.75-8.50)$ & $14.67(11.21-21.11)$ & $6.4(3.1-12.9)$ \\
\hline \multirow[t]{12}{*}{2} & July/11 & 346 & $2.26(4)$ & $2.18 \pm 0.22$ & $3.51(2.85-4.22)$ & $8.52(7.23-10.84)$ & $19.86(14.91-29.71)$ & $7.5(3.7-15.4)$ \\
\hline & Aug/11 & 344 & $1.61(4)$ & $2.40 \pm 0.22$ & $4.53(3.79-5.36)$ & $10.15(8.68-12.76)$ & $21.91(16.80-31.52)$ & $9.7(4.8-19.7)$ \\
\hline & Oct/11 & 335 & $1.58(4)$ & $2.43 \pm 0.32$ & $0.62(0.47-0.77)$ & $1.38(1.18-1.74)$ & $2.96(2.25-4.51)$ & - \\
\hline & Feb/12 & 356 & $5.44(4)$ & $3.32 \pm 0.35$ & $0.92(0.71-1.17)$ & $1.49(1.31-1.82)$ & $2.90(2.08-5.38)$ & $1.8(0.9-3.6)$ \\
\hline & Apr/12 & 348 & $3.95(4)$ & $2.15 \pm 0.20$ & $0.89(0.73-1.06)$ & $2.18(1.84-2.81)$ & $5.16(3.84-7.80)$ & $1.9(0.9-3.9)$ \\
\hline & Jun/12 & 351 & $2.44(4)$ & $2.08 \pm 0.19$ & $1.55(1.28-1.86)$ & $4.30(3.60-5.60)$ & $9.61(7.12-14.51)$ & $3.5(1.8-7.1)$ \\
\hline & Sep/12 & 315 & $2.25(4)$ & $2.04 \pm 0.21$ & $1.76(1.43-2.12)$ & $4.44(3.75-5.70)$ & $11.25(8.17-17.81)$ & $3.8(1.8-7.7)$ \\
\hline & Nov/12 & 352 & $1.38(4)$ & $2.31 \pm 0.22$ & $1.83(1.53-2.17)$ & $4.24(3.62-5.35)$ & $9.44(7.14-13.76)$ & $3.9(1.9-8.0)$ \\
\hline & Feb/13 & 356 & $4.35(4)$ & $2.48 \pm 0.21$ & $2.70(2.13-3.42)$ & $5.90(4.80-8.48)$ & $12.42(8.61-21.96)$ & $5.8(2.8-11.7)$ \\
\hline & May/13 & 352 & $2.37(4)$ & $1.77 \pm 0.17$ & $2.52(2.04-3.07)$ & $7.53(6.14-10.26)$ & $21.41(14.86-35.72)$ & $5.4(2.6-11.0)$ \\
\hline & $\mathrm{Jul} / 13$ & 356 & $2.37(4)$ & $2.11 \pm 0.19$ & $2.30(1.92-2.73)$ & $5.75(4.84-7.40)$ & $13.76(10.22-20.66)$ & $4.9(2.4-10.0)$ \\
\hline & Sep/13 & 345 & $2.81(4)$ & $2.09 \pm 0.20$ & $1.76(1.43-2.11)$ & $4.65(3.55-6.79)$ & $10.77(7.99-16.33)$ & $3.8(1.8-7.7)$ \\
\hline
\end{tabular}

a Total number of mites used to calculate the concentration-response curves.

b Slope and standard error.

c Lethal concentration ( $\mathrm{mg} / \mathrm{L})$ and $95 \%$ confidence interval.

d Resistance ratio: ratio $(95 \% \mathrm{CI})$ of the $\mathrm{LC}_{50}$ between resistance and susceptible populations, calculated using the Robertson and Preisler (1992) method. 
Table 2

Abamectin toxicity for T. urticae populations considered resistant in the Lower Middle São Francisco Valley.

\begin{tabular}{|c|c|c|c|c|c|c|}
\hline Population & $N^{\mathrm{a}}$ & $\chi^{2}(\mathrm{DF})$ & Slope $\pm \mathrm{SE}^{\mathrm{b}}$ & $\mathrm{LC}_{50}(95 \% \mathrm{CI})^{\mathrm{c}}$ & $\mathrm{LC}_{95}(95 \% \mathrm{CI})$ & $\mathrm{RR}_{50}(95 \% \mathrm{CI})^{\mathrm{d}}$ \\
\hline Susceptible & 477 & $4.33(6)$ & $0.70 \pm 0.06$ & $0.00068(0.00044-0.00106)$ & $0.149(0.076-0.451)$ & - \\
\hline 10 & 330 & $0.36(4)$ & $1.62 \pm 0.19$ & $1.66(1.20-2.13)$ & $16.41(11.31-28.62)$ & $2406(1367-4235)$ \\
\hline 11 & 345 & $6.68(4)$ & $1.84 \pm 0.17$ & $2.19(1.43-3.15)$ & $17.71(9.86-54.73)$ & $3230(1904-5481)$ \\
\hline 5 & 349 & $4.35(4)$ & $2.38 \pm 0.20$ & $2.29(1.79-2.92)$ & $11.28(7.71-20.41)$ & $3387(2026-5663)$ \\
\hline 6 & 341 & $3.23(4)$ & $2.22 \pm 0.21$ & $3.00(2.47-3.59)$ & $16.55(12.46-24.53)$ & $4433(2630-7471)$ \\
\hline 9 & 331 & $7.65(4)$ & $1.84 \pm 0.17$ & $3.76(2.52-5.80)$ & $29.22(14.94-112.78)$ & $5545(3273-9396)$ \\
\hline 7 & 314 & $5.98(4)$ & $1.91 \pm 0.18$ & $4.32(2.99-6.16)$ & $31.34(17.76-89.53)$ & $6370(3761-10790)$ \\
\hline 3 & 338 & $7.08(4)$ & $2.30 \pm 0.20$ & $4.68(3.38-6.59)$ & $24.17(14.61-59.91)$ & $6903(4118-11571)$ \\
\hline 4 & 340 & $8.25(4)$ & $1.87 \pm 0.18$ & $5.15(3.30-7.73)$ & $38.70(20.66-140.12)$ & $7590(4487-12839)$ \\
\hline 8 & 339 & $3.57(4)$ & $1.87 \pm 0.18$ & $5.61(4.55-6.81)$ & $42.24(29.97-68.43)$ & $8272(4883-14015)$ \\
\hline
\end{tabular}

a Total number of mites used to calculate the concentration-response curves.

b Slope and standard error.

c Mean lethal concentration (mg/L) and 95\% confidence interval.

d Resistance ratio: ratio $(95 \% \mathrm{CI})$ of the $\mathrm{LC}_{50}$ between resistance and susceptible populations, calculated using the Robertson and Preisler (1992) method.

\section{Discussion}

The results of the present survey clearly show that abamectin has been intensively used in the Lower Middle São Francisco Valley to control T. urticae in grapevines, and the management of resistance to this acaricides has been neglected. Out of the $20 \mathrm{~T}$. urticae populations tested, 9 (45\%) were shown to be resistant to abamectin when exposed to the $9 \mathrm{mg} / \mathrm{L}$ diagnostic concentration. Resistance to abamectin has also been observed in other surveyed populations using diagnostic concentrations lower than those used in the present study (Stumpf and Nauen, 2002; Khajehali et al., 2011). In Brazil, monitoring of $T$. urticae resistance through diagnostic concentrations of abamectin $(4.79 \mathrm{mg} / \mathrm{L})$ and fenpyroximate $(46.3 \mathrm{mg} / \mathrm{L})$ has been performed with 29 populations collected in different crops in 15 municipalities of the state of São Paulo (Sato et al., 2009). The authors observed a frequency of abamectin and fenpyroximate resistant individuals of up to $82 \%$ and $95 \%$, respectively. The initial frequency of resistance genes and intensity of acaricide selective pressure may result in different resistance levels among populations of a certain region (Osakabe et al., 2009). However, resistance to abamectin has been shown to be unstable (Stumpf and Nauen, 2002; Sato et al., 2005, 2009), which leads to a decreasing frequency of resistant individuals after relaxing sprays, favoring management.

The climatic conditions of the Lower Middle São Francisco Valley favorably influence $T$. urticae biology. It is a region with high mean annual temperatures and low relative humidity (da Silva et al., 2009). The T. urticae life cycle at $30^{\circ} \mathrm{C}$ is approximately 7 days (Adb El-Wahed and El-Halawany, 2012). The mean annual temperature in the Lower Middle São Francisco Valley over the last four years was $27^{\circ} \mathrm{C}$, and the relative humidity was 54\% (EMBRAPA, 2013). These conditions in association with the high reproductive potential of $T$. urticae increase the population growth rate and number of annual generations and, consequently, favor the increased frequency of resistant individuals because of the intense use of abamectin. T. urticae can develop up to 37 generations per year under these climatic conditions (Riahi et al., 2013). In other wine producing regions of Brazil, such as the Serra Gaúcha (municipality of Bento Gonçalves) in the state of Rio Grande do Sul, the climate is temperate and humid and the mean annual temperature is $16{ }^{\circ} \mathrm{C}$ (Tonietto et al., 2012), which might explain why T. urticae is not considered a mite pest in this region and there are no reports of resistance of this pest to acaricides in grapevines of that state.

Most T. urticae resistant populations in the present study were located on the western side of the map, and most of the susceptible populations were located farther east (Fig. 1). In the Lower Middle São Francisco Valley, the predominant wind direction is from east and southeast to west (WINDFINDER, 2013), which may have influenced the distribution of resistant populations in the west part of the region. The distance and destination of mites that disperse by wind are important factors that influence population distribution (Kennedy and Smitley, 1985; Osakabe et al., 2005, 2008). Dispersion studies with mites of the family Tetranychidae suggest that wind is the main dispersion strategy over long distances (Bell et al., 2005; Bergh, 2001). The dispersion and colonization behavior of mites also affects the distribution of acaricide resistance genes (GraftonCardwell et al., 1991).

The LC values fluctuated in both vineyards monitored over time (Table 1). The wine production of the studied region is directed to external and domestic markets; however, in the second semester of the year, it is primarily destined for export because in this period, the Northern Hemisphere is in the off season, which contributes to a higher trade value (Araújo, 2004; Lazzaroto and Fioravanço, 2013). A reduction in the LC values was observed in the beginning and middle of the second semester in both monitored vineyards (Table 1). This is the time of year before the flowering and fruiting of grapevines. During this period, acaricide application is reduced because it is necessary to comply with the maximum residue limits allowed by law in the exported fruits. However, in vineyard 1 , whose production in the first semester is destined for the domestic market, there was a consistent and progressive increase in LC values over the studied period. Coincidentally, in this vineyard, the producer kept legumes such as $C$. ensiformis and weeds between the grapevines inter rows to protect the soil, and some of these plants were T. urticae hosts. Although the producer controlled the mite in the vineyard, the mites must have been exposed to abamectin subdoses in non-target plants ( $C$. ensiformis and weeds), favoring the increase in resistance. These mites might have subsequently migrated to the vineyard with a higher frequency of resistance. Apparently, keeping a clear grapevine crop favors resistance management.

The $T$. urticae populations resistant to abamectin tested in the present study also showed resistance to bifenthrin. Likely, resistance to abamectin and bifenthrin may have developed concurrently in the populations here assessed, as observed by Ferreira et al. (2015) in other T. urticae populations to abamectin and METI group. The bifenthrin dose recommended for T. urticae control is $50 \mathrm{mg} / \mathrm{L}$. This concentration is much lower than the $\mathrm{LC}_{50}$ estimated in the present study, which shows that the bifenthrin dose recommended by the manufacturer for $T$. urticae control is insufficient to control the mite. In Belgium, a T. urticae population was exposed to successive bifenthrin pulverizations in rotation with other acaricides, and this population subsequently showed resistance ratios to bifenthrin of approximately 2000-fold (van Leeuwen 
Table 3

Toxicity of carbosulfan and bifenthrin to T. urticae populations of the Lower Middle São Francisco Valley considered resistant to abamectin.

\begin{tabular}{|c|c|c|c|c|c|c|c|}
\hline Product & Population & $\mathrm{N}^{\mathrm{a}}$ & $\chi^{2}(\mathrm{DF})$ & Slope $\pm \mathrm{SE}^{\mathrm{b}}$ & $\mathrm{LC}_{50}(95 \% \mathrm{CI})^{\mathrm{c}}$ & $\mathrm{LC}_{95}(95 \% \mathrm{CI})^{\mathrm{c}}$ & $\mathrm{RR}_{50}(95 \% \mathrm{CI})^{\mathrm{d}}$ \\
\hline \multirow[t]{10}{*}{ Carbosulfan } & Susceptible & 360 & $2.35(4)$ & $2.23 \pm 0.19$ & $715(606-846)$ & $3902(2913-5786)$ & - \\
\hline & 5 & 332 & $3.49(4)$ & $3.08 \pm 0.28$ & $720(622-833)$ & $2462(1960-3350)$ & $1.0(0.8-1.3)$ \\
\hline & 4 & 327 & $6.54(4)$ & $1.80 \pm 0.17$ & $751(515-1120)$ & $6123(3213-21283)$ & $1.1(0.8-1.4)$ \\
\hline & 10 & 349 & $4.68(4)$ & $2.57 \pm 0.22$ & $1079(847-1378)$ & $4700(3234-8477)$ & $1.5(1.2-1.9)$ \\
\hline & 11 & 360 & $6.52(4)$ & $2.13 \pm 0.18$ & $1094(796-1518)$ & $6455(3875-15944)$ & $1.5(1.2-1.9)$ \\
\hline & 3 & 360 & $6.54(4)$ & $1.80 \pm 0.16$ & $1303(903-1876)$ & $10563(5788-32341)$ & $1.8(1.4-2.4)$ \\
\hline & 7 & 344 & $4.62(4)$ & $2.26 \pm 0.20$ & $1324(1021-1729)$ & $7076(4617-14110)$ & $1.9(1.5-2.4)$ \\
\hline & 9 & 335 & $5.96(4)$ & $2.41 \pm 0.20$ & $1448(1091-1931)$ & $6931(4491-14347)$ & $2.0(1.6-2.6)$ \\
\hline & 8 & 349 & $4.56(4)$ & $2.65 \pm 0.23$ & $1588(1259-2015)$ & $6612(4591-11752)$ & $2.2(1.8-2.8)$ \\
\hline & 6 & 341 & $3.64(4)$ & $2.29 \pm 0.21$ & $2132(1783-2527)$ & 11095 (8377-16277) & $3.0(2.3-3.8)$ \\
\hline \multirow[t]{10}{*}{ Bifenthrin } & Susceptible & 360 & $1.02(4)$ & $2.76 \pm 0.30$ & $8.7(7.3-10.2)$ & $34(27-49)$ & - \\
\hline & 8 & 315 & $3.40(4)$ & $2.12 \pm 0.20$ & $1411(1158-1699)$ & $8378(6162-12804)$ & $162(125-208)$ \\
\hline & 7 & 343 & $4.02(4)$ & $2.07 \pm 0.20$ & $1413(1062-1822)$ & $8744(5791-16984)$ & $162(126-208)$ \\
\hline & 6 & 358 & $3.88(4)$ & $2.32 \pm 0.21$ & $1585(1337-1865)$ & $8070(6134-11733)$ & $182(143-230)$ \\
\hline & 4 & 311 & $6.09(4)$ & $1.97 \pm 0.20$ & $1724(1166-2437)$ & $11780(6851-32827)$ & $197(152-256)$ \\
\hline & 9 & 360 & $1.36(4)$ & $2.23 \pm 0.21$ & $1753(1457-2076)$ & 9523 (7211-13959) & $201(157-256)$ \\
\hline & 10 & 345 & $0.94(4)$ & $2.45 \pm 0.22$ & $2060(1734-2423)$ & $9622(7420-13679)$ & $236(186-299)$ \\
\hline & 11 & 360 & $6.11(4)$ & $1.87 \pm 0.17$ & $2844(2000-3979)$ & $21432(12337-58061)$ & $326(253-419)$ \\
\hline & 5 & 336 & $5.81(4)$ & $2.71 \pm 0.23$ & 3669 (2796-4829) & 14795 (9974-28460) & $420(334-528)$ \\
\hline & 3 & 360 & $6.54(4)$ & $2.15 \pm 0.18$ & $4271(3122-5962)$ & $24792(14792-61876)$ & $489(385-622)$ \\
\hline
\end{tabular}

a Total number of mites used to calculate the concentration-response curves.

b Slope and standard error.

c Mean lethal concentration (mg/L) and confidence interval at 95\%.

d Resistance ratio: ratio (95\% CI) of the $\mathrm{LC}_{50}$ between resistance and susceptible populations, calculated using the Robertson and Preisler (1992) method.

et al., 2005). Conversely, in the Netherlands, $60 \%$ of the T. urticae populations resistant to abamectin were also resistant to bifenthrin (Khajehali et al., 2011).

The underlying mechanisms of resistance in the populations evaluated in this work have not been studied yet. Resistance of T. urticae to abamectin has been recently associated to point alteration at the position G326E in the glutamate-gated chloride channel (GluCl) (Dermauw et al., 2012). Additionally, Riga et al. (2014) showed that a cytochrome P450-dependent monooxygenase (CYP392A16) was also associated with high levels of resistance to abamectin. However, these authors did not find any activity of this enzyme towards bifenthrin in T. urticae, which may suggest no cross resistance between both acaricides, and thus, our finding strengths the hypothesis of concomitant resistance development. Resistance to bifenthrin has been showed to be linked to both para sodium channel mutations (Tsagkarakou et al., 2009) and to increased esterase metabolism (van Leeuwen and Tirry, 2007). The hypothesis of target site alteration is very likely in the Valley populations because no association with abamectin resistance was observed. Therefore, it will be important to evaluate such mechanisms in the Valleys' populations using existing diagnostic tools or to identify potential novel mutations present in those mite populations.

Among the three products registered for T. urticae control on grapevines in Brazil, carbosulfan was the only product to which the tested populations were not resistant. Although resistance to carbosulfan was not observed, the $\mathrm{LC}_{50}$ values estimated in the present study were higher than the concentration recommended for T. urticae control, which is $400 \mathrm{mg} / \mathrm{L}$. The recommended concentration might not be efficient in the field even with a laboratorysusceptible population. However, carbosulfan is not used in the studied region because its metabolites (carbofuran, 3-hydroxycarbofuran and 3-ceto-carbofuran) (Nigg et al., 1984; Soler et al., 2006) can be detected in residue analyses, making grape sales and export difficult. Carbofuran is banned from use in most of the world, including the European common market, which is an important export market (RAS, 2011).

In conclusion, the failures of $T$. urticae control with abamectin in grapevines of the Lower Middle São Francisco Valley are associated with resistance. Resistance to bifenthrin was also confirmed in the present study. Carbosulfan is not used by the producers in the region because of the possibility of detecting carbofuran in residue analyses of grapes designated for the external market. Therefore, an increase in the number of acaricides registered for T. urticae control in grapevine crops in Brazil could facilitate resistance management.

\section{Acknowledgments}

We would like to thank the National Council for Scientific and Technological Development (Conselho Nacional de Desenvolvimento Científico e Tecnológico - CNPq) for providing a Masters scholarship to the first author and the Pernambuco Research and Technology Foundation (Fundação de Amparo a Ciência e Tecnologia de Pernambuco - FACEPE) for the financial support through the Student Mobility Financial Aid (Auxílio Mobilidade ao Discente - AMD).

\section{References}

Abbott, W.S., 1925. A method of computing the effectiveness of an insecticide. J. Econ. Entomol. 18, 265-267.

AGROFIT, 2013. Sistema de agrotóxicos Fitossanitários do Ministério da Agricultura, Pecuária e Abastecimento. http://extranet.agricultura.gov.br/agrofit_cons/ principal agrofit cons (accessed 20.04.13).

Araújo, J.L.P., 2004. Mercado, comercialização, custos e rentabilidade. Cultivo da Videira. Embrapa Semiárido. http://sistemasdeproducao.cnptia.embrapa.br/ FontesHTML/Uva/CultivodaVideira/custos.htm (accessed 14.01.14).

Adb El-Wahed, N.M., El-Halawany, A.S., 2012. Effect of temperature degrees on the biology an life table parameters of Tetranychus urticae on two pear varieties. Egypt. Acad. J. Biol. Sci. 4, 103-109.

Bell, J.R., Bohan, D.A., Weyman, G.S., 2005. Ballooning dispersal using silk: world fauna, phylogenies, genetics and models. Bull. Entomol. Res. 95, 69-114.

Bergh, J.C., 2001. Ecology and aerobiology of dispersing citrus rust mites (Acari: eriophyidae) in Central Florida. Environ. Entomol. 30, 319-326.

Botton, M., 2005. Pragas da videira. Sistema de produção de uva de mesa no norte de Minas Gerais. Embrapa Uva e Vinho. http://www.cnpuv.embrapa.br/publica/ sprod/MesaNorteMinas/pragas.htm (accessed 25.01.12).

Carmona, M.M., 1996. Fundamentos de acarologia agrícola. Fundação Calouste Gulbenkian, Lisboa.

da Silva, P.C.G., Correia, R.C., Soares, J.M., 2009. Histórico e importância socioeconômica. In: Soares, J.M., Leão, P.C.S. (Eds.), A Vitivinicultura No Semiárido Brasileiro. Embrapa Informação Tecnológica, Brasília, pp. 21-34.

Dermauw, W., Ilias, A., Riga, M., Tsagkarakou, A., Grbi, M., Tirry, L., van Leeuwen, T., Vontas, J. 2012. The cys-loop ligand-gated ion channel gene family of 
Tetranychus urticae: implications for acaricide toxicology and a novel mutation associated with abamectin resistance. Insect Biochem. Mol. Biol. 42, 455-465.

Domingos, C.A., Melo, J.W.S., Oliveira, J.E.M., Gondim Jr., M.G.C., 2014. Mites on grapevines in northeast Brazil: occurrence, population dynamics and withinplant distribution. Int. J. Acarol. 40, 145-151.

Duso, C., Kreiter, S., Tixier, M.S., Pozzebon, A., Malagnini, V., 2010. Biological control of mites in European vineyards and the impact of natural vegetation. In: Sabelis, M.W., Bruin, J. (Eds.), Trends in Acarology: Proceedings of the 12th International Congress. Springer, Dordrecht, pp. 399-407.

EMBRAPA, 2013. Médias anuais da estação agrometeorológica de Bebedouro. Embrapa Semiárido. http://www.cpatsa.embrapa.br:8080/servicos/dadosmet/ ceb-anual.html (accessed 22.11.13).

Fachinello, J.C., 2001. Produção integrada de frutas: um breve histórico. Inf. Agropec $22,15-18$

Ferreira, C.B.S., Andrade, F.H.N., Rodrigues, A.R.S., Siqueira, H.A.A., Gondim Jr., M.G.C., 2015. Resistance in field populations of Tetranychus urticae to acaricides and characterization of the inheritance of abamectin resistance. Crop Prot. 67, 77-83.

Finney, D.J., 1971. Probit Analysis, third ed. Cambrige University Press, London.

Grafton-Cardwell, E.E., Granett, J., Normington, S.M., 1991. Influence of dispersal from almonds on the population dynamics and acaricide resistance frequencies of spider mites infesting neighboring cotton. Exp. Appl. Acarol. 10, 187-212.

Haji, F.N.P., Alencar, J.A., 2000. Pragas da videira e alternativas de controle. In: Leão, P.C.S., Soares, J.M. (Eds.), A Viticultura No Semi-árido Brasileiro, pp. 273-291. Embrapa Semiárido, Petrolina.

Haji, F.N.P., Moreira, A.N., Lopes, P.R.C., Ferreira, R.C.F., Lopes, L.M.M., Freire, L.C.L., 2001a. Produção integrada de uvas finas. Inf. Agropec 22, 57-60.

Haji, F.N.P., Moreira, A.N., Ferreira, R.C.F., Alencar, J.A., Barbosa, F.R., 2001b. Monitoramento e determinação do nível de ação do ácaro-rajado na cultura da uva http://www.infoteca.cnptia.embrapa.br/bitstream/doc/151809/1/CTE68.pdf (accessed 12.04.13).

Halliday, W.R., Burnham, K.P., 1990. Choosing the optimal diagnostic dose for monitoring inseticide resistance. J. Econ. Entomol. 83, 1151-1159.

Herron, G.A., Learmonth, S.E., Rophail, J., Barchia, I., 1997. Clofentezine and fenbutatin oxide resistance in the two-spotted spider mite, Tetranychus urticae Koch (Acari: Tetranychidae) from deciduous fruit tree orchards in Western Australia. Exp. Appl. Acarol. 21, 163-169.

IRAC, 2009. Method No 004. In: IRAC (Ed.), IRAC Susceptibility Test Methods Series, Insecticide Resistance Action Committee, Brussels.

James, D.G., Prischmann, D., 2010. The impact of sulfur on biological control spider mires in Washington State vineyeard and hop yards. In: Sabelis, M.W., Bruin, J. (Eds.), Trends in Acarology: Proceedings of the 12th International Congress. Springer, Dordrecht, pp. 477-482.

Kabir, M.K.H., Chapman, R.B., Penman, D.R., Popay, A.J., 1991. Use of discriminating concentration for monitoring propargite resistance in two spotted spider mite. N. Z. Plant. Prot. 44, 252-256.

Kennedy, G.G., Smitley, D.R., 1985. Dispersal. In: Helle, W., Sabelis, M.W. (Eds.), Spider Mites: Their Biology, Natural Enemies and Control, vol. 1A. Elsevier, Amsterdam, pp. 236-238.

Khajehali, J., van Nieuwenhuyse, P., Demaeght, P., Tirry, L., van Leeuwen, T., 2011. Acaricide resistance and resistance mechanisms in Tetranychus urticae populations from rose greenhouse in the Netherlands. Pest. Manag. Sci. 67, 1424-1433.

Kim, Y.J., Park, H.M., Cho, J.R., Ahn, Y.J., 2006. Multiple resistance and biochemical mechanisms of pyridaben resistance in Tetranychus urticae (Acari: Tetranychidae). J. Econ. Entomol. 99, 954-958.

Knight, A.L., Beers, E.H., Hoyt, S.C., Rield, H., 1990. Acaricide bioassays with spider mite (Acari: Tetranychidae) on pome fruits: evaluation of methods and selection of discriminating concentrations for resistance monitoring. J. Econ. Entomol. 83, 1752-1760.

Kwon, D.H., Seong, G.M., Kang, T.J., Lee, S.H., 2010. Multiple resistance mechanism to abamectin in the two-spotted spider mite. J. Asia Pac. Entomol. 13, 229-232.

Lazzaroto, J.J., Fioravanço, J.C., 2013. Comércio exterior mundial e brasileiro de uva de mesa: análise de indicadores de competitividade, tendências e sazonalidades. Embrapa Uva e Vinho. http://www.cnpuv.embrapa.br/publica/ documentos/doc080.pdf (accessed 20.09.13).

LeOra-Software, 2005. POLO-plus, POLO for Windows Computer Program, Version 2.0. By LeOra-Software, Petaluma, CA.

Nicastro, R.L., Sato, M.E., da Silva, M.Z., 2010. Milbemectin resistance in Tetranychus urticae (Acari: Tetranychidae): selection, stability and cross-resistance to abamectin. Exp. Appl. Acarol. 50, 231-241.

Nigg, H.N., Stamper, J.H., Knaak, J.B., 1984. Leaf fruit, and soil surface of carbosulfan and its metabolies in Florida citrus groces. J. Agric. Food. Chem. 32, 81-85.

Oliveira, J.E.M., Moreira, A.N., 2009. Manejo integrado de pragas da videira. Embrapa Semiárido. http://ainfo.cnptia.embrapa.br/digital/bitstream/CPATSA2010/41817/1/OPB2579.pdf (accessed 03.04.13).
Osakabe, Mh, Goka, K., Toda, S., Shintaku, T., Amano, H., 2005. Significance of habitat type for the genetic population structure of Panonychus citri (Acari: Tetranychidae). Exp. Appl. Acarol. 36, 25-40.

Osakabe, Mh, Isobe, H., Kasai, A., Masuda, R., Kubota, S., Umeda, M., 2008. Aerodynamic advantages of upside down take-off for aerial dispersal in Tetranychus urticae spider mite. Exp. Appl. Acarol. 44, 165-183.

Osakabe, Mh, Usegi, R., Goka, K., 2009. Evolutionary aspects of acaricide-resistance development in spider mite. Psyche. http://dx.doi.org/10.1155/2009/947439.

Pinheiro, F.A., Adissi, P.J., 2007. Impactos socioambientais e de segurança do alimento na gestão da produção integrada de uvas finas de mesa. Sistemas Gestão 2, 119-140.

RAS, 2011. Rede de Agricultura Sustentável. Lista de agroquímicos proibidos. https:// www.imaflora.org/downloads/biblioteca/RAS Lista de Agroquimicos Proibidos_Novembro_2011.pdf (accessed 09.04.14).

Riahi, E., Shishehbor, P., Nemati, A.R., Saeidi, Z., 2013. Temperature effects on development and life table parameters of Tetranychus urticae (Acari: Tetranychidae). J. Agr. Sci. Tech. 15, 661-672.

Riga, M., Tsakireli, D., Ilias, A., Morou, E., Myridakis, A., Stephanou, E.G., Nauen, R., Dermauw, W., van Leeuwen, T., Paine, M., Vontas, J., 2014. Abamectin is metabolized by CYP392A16, a cytochrome P450 associated with high levels of acaricide resistance in Tetranychus urticae. Insect Biochem. Mol. Biol. 46, 43-53.

Robertson, J.L., Preisler, H.K., 1992. Pesticide Bioassays with Arthropods. CRC Press, Boca Raton.

Roush, R.T., Miller, G.L., 1986. Considerations for design of insecticide resistance monitoring programs. J. Econ. Entomol. 79, 293-298.

SAS Institute, 2002. SAS/STAT User's Guide, Version 8.02, TS Level 2MO. SAS Institute Inc., Cary, NC.

Sato, M.E., da Silva, M.Z., Raga, A., de Souza Filho, M.F., 2005. Abamectin resistance in Tetranychus urticae Koch (Acari: Tetranychidae): selection, cross-resistance and stability of resistance. Neotrop. Entomol. 34, 991-998.

Sato, M.E., da Silva, M.Z., da Silva, R.B., de Souza Filho, M.F., Raga, A., 2009. Monitoramento da resistência de Tetranychus urticae Koch (Acari: Tetranychidae) a abamectin e fenpyroximate em diversas culturas no Estado de São Paulo. Arq. Inst. Biol. 76, 217-223.

Schruft, G.A., 1985. Grape. In: Helle, W., Sabelis, M.W. (Eds.), Spider Mites: Their Biology, Natural Enemies and Control, vol. 1B. Elsevier, Amsterdam, pp. 359-365.

Shah, R., Worner, S.P., Chapman, R.B., 2002. Selection of a discriminating concentration (DC) for propargite-resistance detection and monitoring in Tetranychus urticae (Koch). Pakistan. J. Biol. Sci. 5, 1074-1076.

Silva, A.S., Pessoa, M.C.P.Y., Ferracini, V.L., Chaim, A., Silva, C.M.M.S., Hermes, L.C., 2001. Produção integrada de frutas, o que é? Inf. Agropec 22, 5-14.

Soler, C., Mañes, J., Picó, Y., 2006. Determination of carbosulfan and its metabolites in oranges by liquid chromatography ion-trap triple-stage mass spectrometry. J. Chromatogr. A 1109, 228-241.

Stumpf, N., Nauen, R., 2001. Cross-resistance, inheritance, and biochemistry of mitochondrial electron transport inhibitor-acaricide resistance in Tetranychus urticae (Acari: Tetranychidae). J. Econ. Entomol. 94, 1577-1583.

Stumpf, N., Nauen, R., 2002. Biochemical markers linked to abamectin resistance in Tetranychus urticae (Acari: Tetranychidae). Pestic. Biochem. Phys. 72, 111-121.

Tonietto, J., Madelli, F., Zanus, M.C., Guerra, C.C., Pereira, G.E., 2012. O clima vitícola das regiões produtoras de uva para vinhos finos do Brasil. In: Tonietto, J., Ruiz, V.S., Gomez-Miguel, V.D. (Eds.), Clima, zonificación y tipicidad del vino en regiones vitivinícolas Iberoamericanas. Cyted, Madrid, pp. 111-146.

Tsagkarakou, A., van Leeuwen, T., Khajehali, J., Ilias, A., Grispou, M. Williamson, M.S., Tirry, L., Vontas, J., 2009. Identification of pyrethroid resistance associated mutations in the para sodium channel of the two-spotted spider mite Tetranychus urticae (Acari: Tetranychidae). Insect Mol. Biol. 18, 583-593.

van Leeuwen, T., Tirry, L., 2007. Esterase-mediated bifenthrin resistance in a multiresistant strain of the two-spotted spider mite, Tetranychus urticae. Pes Manage. Sci. 63, 150-156.

van Leeuwen, T., van Pottelberge, S., Tirry, L., 2005. Comparative acaricide susceptibility and detoxifying enzyme activities in field-collected resistant and susceptible strains of Tetranychus urticae. Pest. Manag. Sci. 61, 499-507.

van Leeuwen, T., Vontas, J., Tsagkarakou, A., Dermauw, W., Tirry, L., 2010. Acaricide resistance mechanisms in the two-spotted spider mite Tetranychus urticae and other important Acari: a review. Insect Biochem. Mol. Biol. 40, 563-572.

Whalon, M.E., Mota-Sanchez, D. Hollingworth, R.M., 2008. Analysis of global pesticide resistance in arthropods. In: Whalon, M.E., Mota-Sanchez, D. Hollingworth, R.M. (Eds.), Global Pesticide Resistance in Arthropods. CAB International, Cambridge, pp. 5-31.

WINDFINDER, 2013. Previsão de vento, ondas e tempo. http://pt.windfinder.com/ windstats/windstatistic_petrolina.htm (accessed 21.11.13).

Yu, S.J., 2008. Insecticide resistance. In: Yu, S.J. (Ed.), The Toxicology and Biochemistry of Insecticides. CRC Press, Boca Raton, pp. 215-221. 